\title{
THE COLLECTIVE BARGAINING AGREEMENT AS A LIMITATION ON UNION CONTROL OF EMPLOYEE GRIEVANCES
}

\section{Andrew H. Levy $\dagger$}

Labor unions play an important role in protecting the individual employee from the often formidable power of management. In both the negotiation and implementation of the collective bargaining agreement, the power of organizations representing the interests of many employees counterbalances the once overwhelming power of the employer. ${ }^{1}$ Because unions represent a variety of employees with diverse interests, however, some employees are inevitably dissatisfied with the negotiation of the collective bargaining agreement or with the union's disposition of grievances under the agreement. Yet some commentators have argued that the vitality of the collective bargaining process depends upon the union's absolute control over the procedures for vindicating employee grievances. ${ }^{2}$ The grievance procedures, they feel, are an integral part of the collective bargaining agreement and can function properly only if employees can be denied access to them by employer-union agreement.

This Article argues the contrary: that within the present legal framework for the administration of collective bargaining, greater protection of individual employees may be assured by diminishing union control over the employees' access to the grievance machinery without destroying the vitality of the collective bargaining process. It will attempt to answer this question: What recourse should an employee have when the union either refuses to press his claim or reaches an agreement with management not to his satisfaction? An expansion of the duty of fair representation through reliance upon the contractual provisions would enhance the value of the collective bargaining relationship as a mechanism for balancing the legitimate interests of employer, union, and employee.

The Article will focus on contractual grievances pursued under section 301 of the Labor Management Relations Act (LMRA), ${ }^{3}$ rather Bar.

$\dagger$ B.A. 1966, J.D. 1969, Harvard University. Member, District of Columbia

1 See J. Galbraith, American Capitalism: The Concept of Countervaning POWER (1952).

2 E.g., Cox, Rights Under A Labor Agreement, 69 HARv. L. Rev. 601, 625-27 (1956) [hereinafter cited as Cox].

329 U.S.C. $\$ 185$ (1964). 
than on employee complaints over the negotiation of the labor contract. ${ }^{4}$ In both situations, the same legal label-the duty of fair representation-describes the substantive protection afforded employees against improper union action. But the context in which that duty is exercised differs. ${ }^{5}$

The duty of fair representation is a judicially developed doctrine designed to protect individual employees from a union's bad faith conduct. Because an employee must show union bad faith before a court will consider the merits of his claim, relief is difficult to secure. Although the duty of fair representation should continue to determine when an individual employee can process his own grievance or sue in court, the content of the duty should derive from the provisions of the collective bargaining agreement itself, not from the union's intentions. The substantive provisions of the agreement can provide an objective limit to the union's discretion in settling or dropping grievances and can act as a limitation on the employer's ability to rely upon the union's good faith conduct as a defense. Expanding the duty of fair representation would not afford an employee as much protection as he would obtain from an absolute right to process his own grievance, but it would give him greater assurance than presently exists that the expectations generated by written agreement will not be nullified at will.

\section{The Collective Bargaining Agreement and the EMployer's Right to SUe}

\section{A. The Contract as a Source of Rights and Limitations}

The Supreme Court ruled in Swith v. Evening News Association ${ }^{\circ}$ that under section 301 of the LMRA an individual employee has standing to sue for breach of a collective bargaining agreement. Section 301 grants federal district courts jurisdiction over "[s] uits for violation of contracts between an employer and a labor organization." 7 By

4 The failure to maintain this distinction allows Justice Goldberg in Humphrey v. Moore, 375 U.S. 335 (1964), to take the extreme position that the employer and union can always alter or extinguish the viability of claims under the collective bargaining agreement and thereby render the contract language irrelevant to a determination whether a violation of the duty of fair representation has occurred. $I d$. at 353-54. See generally id. at 359 (Harlan, J., concurring in part and dissenting in part).

5 The National Labor Relations Act (NLRA) itself suggests that the employee's position in grievances differs from his position in negotiations. At least in the absence of any exclusivity clause, $\$ 9(a), 29$ U.S.C. $\$ 159$ (a) (1964), grants an employee the right to "present" grievances to his employer; but the same employee may not bargain with the employer with regard to the negotiation of the contract. Most union constitutions also distinguish the negotiation from the grievance process and establish separate bodies with distinct powers to perform each task.

B 371 U.S. 195 (1962).

729 U.S.C. \$185(a) (1964). 
construing "between" to modify "contracts" rather than "suits," the Court enabled employees to bring suit in federal court under section $301 .^{8}$ It rejected respondent's argument that suits by employees for breach of a collective bargaining contract should be governed by state law, and found that neither the language, the purpose, nor the history of section 301 precludes such suits. ${ }^{9}$

But an employee's standing to sue does not guarantee adjudication of the merits of his claim. The collective bargaining agreement creating the rights he seeks to vindicate under section 301 may limit, modify, or control the enforcement of those rights, subject to the duty of fair representation, by providing for exclusive grievance procedures. $^{10}$ Such control over an employee's ability to vindicate his rights has been the subject of considerable academic debate.

Writing in 1962, Professor Summers took the following position: ${ }^{11}$ An employee has an absolute right under section 9 (a) ${ }^{12}$ of the National Labor Relations Act (NLRA) to process his substantive grievances; the union and employer cannot vest in themselves exclusive control of the remedial procedures in derogation of this right. Although the legislative history is unclear, section 9(a) gives the employee a "right" to veto an undesirable disposition of his grievance prior to arbitration. ${ }^{13}$ In deference to the national policy supporting arbitration, the employee should be permitted to compel arbitration of his claim (the costs to be allocated among union, employer, and employee), but not freely enter the courts at this stage. ${ }^{14}$

8371 U.S. at 200-01. The Court carefully avoided deciding which kinds of substantive contractual claims an employee can bring; rather, it held only that the employee has standing to sue in a state court. See id. at 201 n.9. In his dissent, Justice Black criticized the Court for its failure to decide whether an employee could sue under the particular contractual clause in question. Id. at 204 (Black, J., dissenting).

'Id. at 200-01. The Smith decision was facilitated by the Court's decision five years earlier in Textile Workers Union v. Lincoln Mills, 353 U.S. 448, 456-57 (1957), in which it held that $\S 301$ establishes a foundation for a substantive federal law of collective bargaining.

10 Because the collective bargaining agreement scrutinized in Smith contained no grievance arbitration procedure granting the union control over grievances, it imposed no contractual limit upon an employee's ability to vindicate his claim. See 371 U.S. at 196 n.1.

11 Summers, Individual Rights in Collective Agreenents and Arbitration, 37 N.Y.U.L. REv. 362 (1962) [hereinafter cited as Summers].

1229 U.S.C. $\$ 159$ (a) (1964). The statute provides that the majority union shall be the exclusive representatives of all the employees in such unit for the purposes of collective bargaining in respect to rates of pay, wages, hours of employment, or other conditions of employment: Provided, that any individual employee or a group of employees shall have the right at any time to present grievances to their employer and to have such grievances adjusted, without the intervention of the bargaining representative, as long as the adjustment is not inconsistent with the terms of the collective bargaining contract or agreement then in effect . . . .

13 Summers $376-85$.

14 Id. 400-04. 
Six years earlier, Professor Cox took a different stance: ${ }^{15}$ Too strict a reading of the word "right" disregards the remaining language of section 9(a). The section 9(a) proviso means only that the employer does not commit an unfair labor practice by receiving grievances from employees. ${ }^{16}$ The union and company are still free to agree, as a matter of contract, to grievance procedures granting the union exclusive power to process grievances. ${ }^{17}$ The ability to contract in this manner is important primarily because contractual language is often purposefully ambiguous : all eventualities cannot be foreseen and the process of specification in the contract is tedious and inflexible. The union and employer contemplate the need to bargain continuously about their agreement. To assert that a neutral third party can always discern a "correct" contractual interpretation places too much reliance on a document intended to provide only guidelines. ${ }^{18}$

Cox further argued that: disputes of importance to all members of the bargaining unit should not be placed in the hands of individual employees; interpretation by mutual consent of the union and employer will promote greater acceptance among employees than will an interpretation imposed by an outside party; consistency of application will be more likely if the union controls the grievance process; the ability of individual employees to press grievances freely will undermine the union's position as collective bargaining representative and exacerbate internal political divisions, if any, of the union; and frivolous claims and the costs they generate will be minimized by union control of grievance procedures. ${ }^{19}$

Professor Summers sought to avoid or alleviate these problems by a procedure best described as "arbitrational overkill." By allowing an employee to force any claim to arbitration, he vowed to insure employee rights. To maintain the viability of the contract, he sought to preserve consistency of interpretation by requiring the arbitrator to weigh heavily an interpretation of the contract agreed upon by the employer and union. ${ }^{20}$ Aside from the difficulties of devising standards to determine how much weight should be given to such an interpretation, the major infirmity of this procedure is that it would diminish both the union's incentive to represent fully employee claims and the union's and employer's incentive to settle claims. To rely on

\footnotetext{
15 Cox.

16 Id. 624.

$17 \mathrm{Id}$.

${ }^{18}$ See id. 625-27.

$10 I d$.

20 Summers 404.
} 
the Steelworkers Trilogy ${ }^{21}$ as a basis for encouraging individual access to arbitration mistakenly focuses on arbitration as an end in itself and not merely as the final stage of a series of procedures designed by employer and union to be used by them to promote industrial peace and proper administration of the collective bargaining agreement. ${ }^{22}$ Arbitration is only a last resort.

While the academic struggle continued, ${ }^{23}$ the courts sided with Professor Cox. Individual employees were not only precluded from side-stepping the union-controlled grievance procedures provided for in the contract, but were also incapable of either forcing the union to process them within the contract or processing them themselves within the machinery. ${ }^{24}$ In Black Claweson Co. $v$. International Association of Machinists, ${ }^{25}$ the employer sought a declaratory judgment under section 301 that an employee grievance of wrongful discharge was not arbitrable under the contract. The Second Circuit affirmed a district court decision that the employee could not individually process the grievance or compel the employer to arbitration. ${ }^{26}$ The court concluded that in view of a contractual provision establishing a particular method of processing grievances under union control, chaos in the administration of contracts would be avoided only by adhering to the method agreed upon by the union and employer as the means of settling their differences. The case contained no allegation that the union had violated its duty of fair representation.

Not until Republic Steel Corp. v. Maddox ${ }^{27}$ did the Supreme Court interpret section 9 (a). Maddox sued his employer for severance pay under a contract providing for such pay if the employee was laid off because the mine in which he worked closed permanently. ${ }^{28}$ Although the contract provided for a three-step grievance procedure followed by binding arbitration, Maddox did not attempt to use this

21 United Steelworkers v. American Mfg. Co., 363 U.S. 564 (1960); United Steelworkers v. Warrior \& Gulf Navigation Co., 363 U.S. 574 (1960) ; United Steelworkers v. Enterprise Wheel \& Car Corp., 363 U.S. 593 (1960).

22 See Vaca v. Sipes, 386 U.S. 171, 191 (1967).

${ }^{23}$ E.g., Blumrosen, The Worker and Three Phases of Unionism: Administrative and Judicial Control of the Worker-Union Relationship, 61 MrCH. L. REv. 1435 (1963) [hereinafter cited as Blumrosen, Three Phases of Unionism] ; Blumrosen, Legal Protection for Critical Job Interests: Union-Managenent Authority versus Employee Autonomy, 13 RuTGERS L. REv. 631 (1959); Hanslowe, The Collective Agreement and the Duty of Fair Representation, 14 LAB. L. J. 1052 (1963); Ratner, Some Contemporary Observations on Section 301, 52 GEo. L.J. 260 (1964).

24 But see Hughes Tool Co. v. NLRB, 147 F.2d 69, 72-73 (5th Cir. 1945), in which the Fifth Circuit indicated that, although confined to the machinery provided for in the contract, the employee would be able to use it himself to process his grievance.

25313 F.2d 179 (2d Cir. 1962).

26 Id. at 186.

27379 U.S. 650 (1965).

$281 d$. at 651 . 
procedure, but sued for breach of contract in state court almost three years after his layoff.

The Court indicated that whether an employee can bring suit under the substantive provisions of the contract depends upon an interpretation of its remedial provisions. As a standard for interpreting these provisions, the Court, in effect, established a presumption that the contractually created grievance procedures are exclusive. Only when the contract expressly provides that these procedures are not exclusive can the employee sue under federal contract law. ${ }^{29}$ Absent such a provision, the union must be afforded an opportunity to act on the employee's behalf. ${ }^{30}$

The Court apparently regarded as conclusive the rationale of the arbitration cases ${ }^{31}$ and the express congressional approval of agreedupon grievance machinery as the preferred method for settling disputes and stabilizing the "common law' of the plant." 32 To promote consistency of interpretation, union participation in the processing of grievances, union prestige, and employee convenience, the Court relied on section 203 (d) ${ }^{33}$ as a basis for giving full play to the provisions of the employer-union agreement.

Justice Black dissented, however, on the grounds that such reliance is completely misplaced in an employee's suit under the contract, not only because the arbitration decisions used as precedent were concerned only with the employer-union relationship, but also because an employee claim is inherently prejudiced if always subject to the control of the parties alleged to be acting contrary to his interests. ${ }^{34}$ Moreover, he suggested that confining an employee to the contractual procedure may be unconstitutional, ${ }^{35}$ because a mere contract between employee and union should not deprive courts of jurisdiction in an area in which they have traditionally offered protection to individuals bringing contractual claims. Arbitration lacks many of the procedural safeguards provided in judicial adjudication.

Despite Justice Black's fears, the Court seemed content with the broad sweep of its language and with its reliance on the procedures

$29 \mathrm{Id}$. at $657-58$.

${ }^{30} I d$. at $652-53,657-59$.

31 United Steelworkers v. American MIfg. Co., 363 U.S. 564 (1960); United Steelworkers v. Warrior \& Gulf Navigation Co., 363 U.S. 574 (1960); United Steelworkers v. Enterprise Wheel \& Car Corp., 363 U.S. 593 (1960).

32379 U.S. at 653. (1964):

33 Labor Management Relations Act (LMRA) \$203(d), 29 U.S.C. \$173(d)

Final adjustment by a method agreed upon by the parties is declared to be the desirable method for settlement of grievance disputes arising over the application or interpretation of an existing collective-bargaining agreement. 34379 U.S. at 667-69 (Black, J., dissenting).

35 Id. at 663 . 
established by the agreement. Yet the Court's italicization of the word "attempt" in its statement of the general rule ${ }^{36}$ left open the question of fair representation with respect to the union's performance in processing grievances. By citing Humphrey v. Moore ${ }^{37}$ and NLRB v. Miranda Fuel Co., ${ }^{38}$ the Court indicated that exceptions to its broad statement of deferral to the contractual procedures might develop if the duty of fair representation was breached. Furthermore, by examining (although rejecting) a claim that access to these particular procedures was unavailable, the Court implied that the employee need not attempt to comply with such procedures if access is indeed unavailable. ${ }^{39}$ Under these circumstances evidencing no infirmities in the procedures and no improper union conduct, giving full play to contractual language seems quite reasonable. The Court thus turned towards the views of Professor Cox. ${ }^{40}$

\section{B. Examining the Contract}

If the provisions of the collective bargaining agreement determine the employee's ability to control the processing of his grievance, absent a violation of the duty of fair representation, an effort to protect the rights of employees should begin with an inquiry into whether the contract gives the union exclusive control over the processing of all grievances. That is, is the dispute in question covered by the contract, and does the contract grant the union exclusive control over the grievance machinery?

\section{Whether a Dispute Is Covered by the Grievance-Arbitration Procedure}

When the grievance procedure does not cover, or specifically excludes, a contractual claim by an employee, the employee has standing

36

As a general rule in cases to which federal law applies, federal labor policy requires that individual employees wishing to assert contract grievances must atfempt use of the contract grievance procedure agreed upon by employer and union as the mode of redress.

$I d$. at 652 (emphasis in original) (footnote omitted).

37375 U.S. 335 (1964) (discussed at text accompanying notes 109-12 infra). infra).

38326 F.2d 172 (2d Cir. 1963) (discussed at text accompany notes 78-82

39379 U.S. at 659.

40 In Vaca v. Sipes, 386 U.S. 171, 183-87 (1967), the Court described the circumstances in which the employee may avoid the union's contractual right of absolute control of the grievance procedures. Unless the employee can show both a breach of contract by the employer and a violation of the duty of fair representation by the union, the employee must accept the union's resolution of his grievance. The issue raised by $\$ 9$ (a) was never specifically discussed in the Vaca opinion. Presumably, the Court felt that the issue was settled by its citation to Maddox, and that it was only dealing with the exceptions to the rule, foreshadowed by that case. For further discussion of Vaca, see text accompanying notes 94-100 infra. 
to sue under Smith. But when an employee with a grievance not specifically excluded alleges in court that the dispute is not covered by the grievance-arbitration procedure, the court must adopt a standard for determining the scope of the procedure. If the employee has ignored the grievance procedures of the contract and has come directly to court, the court should defer to the breadth of the contract and dismiss the suit.

In the Steelworkers Trilogy, ${ }^{41}$ the Supreme Court held that an order to compel arbitration would issue unless the collective bargaining agreement expressly excluded the particular question from the arbitration procedure. ${ }^{42}$ If the employee does not attempt to resolve his grievance through the procedures established by the contract, courts should employ a similar standard when confronted with an employee's suit alleging that his grievance is not within the grievance-arbitration clause of the collective bargaining agreement. Such a standard allowing the employee to proceed in court only when the arbitration clause expressly denies coverage of his grievance would at least permit an attempt to resolve the grievance through the contractual procedures. After his suit is dismissed, the employee may seek to have the union process his grievance. If the union presses his grievance fully, it will be resolved at one of the steps of the grievance procedure or taken to arbitration. If the arbitrator rules in favor of the employee on the merits, the employee achieves his goal; if against him, the employee can seek judicial review. A decision by the arbitrator that he lacks jurisdiction gives the employee a determination which should enable

41 United Steelworkers v. American Mfg. Co., 363 U.S. 564 (1960) ; United Steelworkers v. Warrior \& Gulf Navigation Co., 363 U.S. 574 (1960) ; United Steelworkers v. Enterprise Whee1 \& Car Corp., 363 U.S. 593 (1960). For further commentary on these cases, see Hays, The Supreme Court and Labor Law, October Term 1959, 60 Colum. L. REv. 901, 919-35 (1960); Meltzer, The Supreme Court, Arbitrability and Collective Bargaining, 28 U. CFI. L. Rev, 464 (1961) ; Smith \& Jones, The Supreme Court and Labor Dispute: Arbitration, The Emerging Federal Law, 63 Mich. L. Rev. 751 (1965) ; Symposinm: Arbitration and the Courts, 58 Nw. U.L. REv. 466, 494-521, 532-44 (1963).

42 The typical arbitration clause is written in words which cover, without limitation, all disputes concerning the interpretation or application of a collective bargaining agreement. Its words do not restrict its scope to meritorious disputes or two-sided disputes, still less are they limited to disputes which a judge will consider two-sided. Frivolous cases are often taken, and are expected to be taken, to arbitration. What one man considers frivolous another may find meritorious, and it is common knowledge in industrial relations circles that grievance arbitration often serves as a safety valve for troublesome complaints. Under these circumstances it seems proper to read the typical arbitration clause as a promise to arbitrate every claim, meritorious or frivolous, which the complainant bases upon the contract. The objection that equity will not order a party to do a useless act is outweighed by the cathartic value of arbitrating even a frivolous grievance and by the dangers of excessive judicial intervention.

Cox, Current Problems in the Law of Grievance Arbitration, 30 Rocky Mr. L. Rev. 247, 261 (1958), cited in United Steelworkers v. American Mfg. Co., 363 U.S. 564, 568 n.6 (1960). 
him to vindicate his claim in court. Finally, union refusal to process the grievance fully would enable the employee to bring suit claiming a breach of the duty of fair representation.

Such a standard would also prevent questions which the Steelworkers Trilogy sought to confine to the arbitration procedure from being thrown into the courts merely because they were pressed by an employee rather than a union. Employer faith in the grievancearbitration procedure would be reinforced in fulfillment of the congressional policy expressed in section 203(d) of the LMRA.

A more difficult question arises when an employee sues on the contract, claiming the grievance is not covered by the contractually created grievance procedure, after a settlement has been reached by the union and the employer. Many of the reasons for deference to the breadth of the contract when the employee has made no attempt to utilize the grievance procedures of the contract are inappropriate when the employee has made an attempt. In Rothlein v. Armour \& $\mathrm{Co}_{0 .}{ }^{43}$ the Third Circuit clearly indicated that in such cases the courts are to decide the issue of coverage on the merits. Employees sought an accounting and payment of amounts in a pension fund established by an old collective bargaining agreement. The action was brought prior to any attempt to utilize the grievance procedure. The district court granted a stay of all proceedings until such an attempt was made. After the claim was taken through the three steps established by the collective bargaining agreement, the district court granted Armour's motion for summary judgment and held that a "final" determination binding on the courts had been reached. The Third Circuit remanded the case to the district court for a finding whether the accounting for pension funds was the type of dispute contemplated to fall within the grievance procedures of the contract. ${ }^{44}$

Despite the Rothlein case, only limited protection is offered to an employee claiming that his grievance is not covered by the procedures established in the contract. Coverage is usually undisputed. In the traditional categories of grievances-seniority, discipline, pay-coverage will be virtually conceded. Even when coverage is uncertain, courts outside the Third Circuit will not necessarily concur with Rothlein.

\section{Avoiding the Exclusivity of "Exclusive" Procedures}

Once a court determines that as a matter of contractual interpretation the grievance-arbitration procedures over which the union has exclusive control cover the particular grievance, those procedures must

43391 F.2d 574 (3d Cir. 1968).

44 Id. at $579-80$. 
be followed in processing a grievance. An employee may retain some rights after unsuccessfully resorting to these procedures, but failure to use them will generally provide a complete defense to an employee's suit on the contract. The Court in Maddox required that an employee at least attempt to use the established procedures and give the union an opportunity to act on his behalf when the claim is within the contract. ${ }^{45}$

A contrary rule allowing the employee to vindicate substantive claims without being bound by contractual provisions qualifying his ability to vindicate them would undercut both the union's prestige and its ability to establish a uniform and exclusive method for the orderly settlement of grievances. ${ }^{48}$ Moreover, the inclusion of certain language in the collective bargaining agreement is often conditioned on the understanding that such language will be effectuated by the procedures prescribed in the agreement. ${ }^{47}$ Encouraging settlement of grievances within the collective bargaining context in preference to court intervention by requiring "compliance with" or "exhaustion of" the procedures provided for in the contract is also a sound analogue to the doctrine of "exhaustion" in administrative law. ${ }^{48}$

But some courts have found "exhaustion" of the contractual procedures unnecessary even when an employee has completely side-stepped the procedures without approaching the union. ${ }^{49}$ Union hostility, a conspiracy between the employer and the union, ${ }^{50}$ or proof of the futility of resorting to the procedures ${ }^{51}$ nullifies an employer's defense based on failure to comply with the contractual procedures. Effective access to the grievance procedures must be available for their mere existence to preclude private suit. ${ }^{52}$ Bare allegations of union hostility are insufficient to allow complete avoidance of the grievance-arbitration procedures, ${ }^{53}$ but an employee is permitted to initiate his own suit when the evidence reveals an inherent conflict of interest between the union and the employee. ${ }^{54}$ Similarly, when either party repudiates the griev-

45 Note 36 supra.

46379 U.S. at 653.

47 See Cox 606.

48 See I. Jaffe, Judicial Control of Administrative Action 424-58 (1965).

49 Some of these cases were decided prior to Vaca v. Sipes, 386 U.S. 171 (1967), which confines employees to the remedies established by the collective bargaining agreement unless the union breaches its duty of fair representation. But Vaca probably does not invalidate many of the prior cases based on an "exhaustion" rationale, because the same activity making exhaustion unnecessary would now be deemed a violation of the duty of fair representation.

50 Hiller v. Liquor Salesmen's Local 2, 338 F.2d 778 (2d Cir. 1964).

61 Desrosiers v. American Cyanamid Co., 377 F.2d 864 (2d Cir. 1967). 1967).

52 Richardson v. Communication Workers Local 7495, 267 F. Supp. 403 (D. Neb.

63 Wade v. Southern Pac. Co., 243 F. Supp. 307 (S.D. Tex. 1965).

5\$ Chapman v. Southeast Region ILGWU Fealth \& Welfare Recreation Fund, 280 F. Supp. 766 (D.S.C. 1968). The conflict of interest referred to here should be distinguished from that raised by the plaintiffs in Humphrey v. Moore, 375 U.S. 
ance procedures or when the breach effectively rescinds the entire contract (including any grievance procedure), ${ }^{55}$ employees may be permitted to disregard the procedures.

An employee's unsuccessful attempt to use the grievance machinery facilitates proof of its unavailability. But a formal attempt may be unnecessary. ${ }^{56}$ In a suit alleging racial discrimination by the union and inadequate grievance procedures, the Supreme Court discussed the attempt requirement of Maddox:

Here the complaint alleges in the clearest possible terms that a formal effort to pursue contractual or administrative remedies would be absolutely futile. Under these circumstances, the attempt to exhaust contractual remedies, required under Maddox, is easily satisfied by petitioners' repeated complaints to company and union officials, and no time-consuming formalities should be demanded of them. ${ }^{57}$

If the employee cannot demonstrate the unavailability of the contractual procedures, the rule requiring him to attempt to use them is rigorously enforced. ${ }^{58}$ Regardless of the nature of the grievance, he

335 (1964). In Chapman, the conflict of interest arose because the union could support the employees' claims in arbitration only by arguing the illegality of a provision it had inserted into the contract in violation of the South Carolina rightto-work law. The union had to choose between the mutually inconsistent alternatives of supporting its own interests or those of certain employees. But in Humphrey, the union was engaging in the traditional union function of balancing the interests of two groups within the union when it dovetailed two seniority lists and thereby caused some employees to lose seniority. Nothing in the relationships and contractual provisions predetermined the decision or impaired the union's ability to make a rational choice. Of course, once the decision was made, the union obviously had an interest in upholding its validity; but that interest does not vitiate the integrity of its decision between the two competing groups of employees. See $280 \mathrm{~F}$. Supp. at $770-71$.

55 Cf. Drake Bakeries Inc. v. American Bakery Workers Local 50, 370 U.S. 254, 262-63 (1962). In Woody v. Sterling Aluminum Prods. Inc., $243 \mathrm{~F}$. Supp. 755 (E.D. Mo. 1965), aff'd, 365 F.2d 448 (8th Cir. 1966), cert. denied, 386 U.S. 957 (1967), the district court dismissed the amended second complaint, in which the suing employees sought specific performance of the grievance procedures, because the initial complaint as well as the intervening activities of the employer, the union, and the employees demonstrated a repudiation of these procedures.

56 See Desrosiers v. American Cyanamid Co., 377 F.2d 864, 870-71 (2d Cir. 1967). But see Brown v. Truck Drivers Local 355, 264 F. Supp. 776 (D. Md. 1967).

57 Glover v. St. Louis-S.F. Ry., 393 U.S. 324, 331 (1969).

58 The wording of the employee's allegations is also subject to judicial scrutiny. At least one district court has held that merely alleging attempts to enforce rights under the collective bargaining agreement is insufficient; rather, an employee must allege an attempt to use the grievance procedures. See Brown v. Truck Drivers Local 355, 264 F. Supp. 776 (D. Md. 1967), in which an attempt to distinguish Maddox on the grounds that there the employee could initiate the procedure himself was also rejected by the court. But some cases evidence greater flexibility. In Boone v. Armstrong Cork Co., 384 F.2d 285 (5th Cir. 1967), the Fifth Circuit excused a failure to file a timely grievance, which precluded any use of the grievance procedure, because the parties' common misconception of their contractual obligations prevented the employee from attempting to have the union process his claim. The Fifth Circuit remanded the case to the district court with instruc- 
must afford the union an opportunity to act on his behalf in a claim under the contract. Unrestrained by this requirement of initial resort to the contractual procedures, ${ }^{59}$ individual employees could undermine industrial self-government and the continuity of collective bargaining by bringing employers into court at will. ${ }^{60}$

But under what circumstances may the employee obtain judicial relief after the union has secured a settlement or resolution unacceptable to the aggrieved employee? The rigorous enforcement of the requirement that an attempt be made to use the contractual procedures does not dispose of this question. The Court's general willingness to defer to the contractual provisions ${ }^{61}$ may not be determinative. The italicization of the word "attempt" in Maddox supports the view that an employee may seek judicial relief after exhausting his contractual remedies. A judicially devised scheme envisioning nonfinal settlements would still permit resolution of many grievances under the contractual procedures; subsequent judicial examination of the issue would benefit from findings made under the procedures; and the parties' initial reliance upon the contractual remedies would have a therapeutic effect. ${ }^{62}$

But reading Maddox to permit broad judicial review of final determinations ${ }^{63}$ under the grievance procedure ignores the rationale for the Court's requirement that an employee attempt to utilize contractual remedies before bringing suit. The Court suggested that only

tions to stay the proceedings until the parties had the opportunity to utilize the grievance procedure. The court stated:

In view of the strong policy favoring resort to contract grievance procedures

before the courts are presented with this type dispute, we feel that under the

facts the company has not wrongfully refused to process the grievance so as

to eliminate the requirement that the process be used.

Id. at 290 .

59 The requirement of initial resort to the contractual procedures contemplates that the employee will allow sufficient time for the procedures to operate. Although he may avoid unduly protracted procedures, the employee does not satisfy the requirement by filing suit only three weeks after invoking the final grievance procedure. See Stumo v. United Air Lines, Inc., 382 F.2d 780, 787 (7th Cir. 1967), cert. denied, 389 U.S. 1042 (1968).

${ }^{60}$ If the exclusive grievance procedures controlled by the union provide for arbitration, the employer might conceivably prefer a judicial determination to arbitration for a particular grievance. In that case, he might invite an employee suit, ignore the employee's failure to exhaust or comply with the contractually agreedupon procedures, defend the action on the merits, and thereby embarrass the union and diminish its prestige. Absent a breach of the duty of fair representation, however, the union faced with this conduct would be able to sue the employer for breach of contract and to compel arbitration pursuant to its contractual control over processing grievances.

61 Text accompanying notes 24-33 supra.

62 See Donnelly v. United Fruit Co., 40 N.J. 61, 190 A.2d 825 (1963). Although requiring an attempt to exhaust contractual remedies through the union, the court held that the employee could compel arbitration even when the union settled the claim prior to arbitration. The employee was thus able to act within the confines of the contractual procedures while ignoring the union's power to control them.

63 The phrase "final determination" here includes a union's decision not to process a grievance. 
union refusal to process, perfunctory processing, or breach of the duty of fair representation in processing would overcome the policy favoring union-employer settlement. Despite occasional cases interpreting Mad$d o x$ to allow an employee suit simply because the union refused to process his claim to completion, ${ }^{64}$ most courts have concluded that under Maddox a union's resolution of a grievance bars the employee from subsequently bringing suit on the grievance, ${ }^{65}$ absent a breach of the duty of fair representation.

The most important cases ${ }^{66}$ supporting this majority view arose in the Sixth Circuit out of an incident in the cafeteria of the Union News Company. Concerned about high costs and poor performance at a lunch counter where the plaintiff-employee worked with a crew of about one dozen persons, the company, with the union's concurrence, instituted a temporary layoff of five employees for a test period. During the test period, performance at the lunch counter improved significantly and the employees were consequently discharged with the union's consent. Two of the discharged employees sued under a provision permitting discharge only for "just cause," but each was rebuffed in the Sixth Circuit on the ground that the collective bargaining agreement, by allowing the union, pursuant to its statutory status of exclusive representative, to determine with the employer the contract's meaning, provided a conclusive, affirmative defense to an employee suit.

Dissenting to the denial of certiorari in Simmons $v$. Union Neres, ${ }^{67}$ Justice Black pointed out the impropriety of allowing the employer and the union, acting under the guise of "interpreting" the collective bargaining agreement, to dispose of potentially valid employee claims. He added that the employer was unable to present any evidence that one of the discharged employees had done anything to lower profits, and that another discharged employee had offered to prove that the office girl who counted the money had subsequently been discharged for embezzling lunch counter funds. Concluding that as a matter of law the absence of personal guilt precludes discharge for "just cause," Justice Black argued that union-employer power to effect a final settlement of an employee grievance should be limited.

64 See Simmons v. States Marine Lines, Inc., 267 F. Supp. 384 (E.D. Pa. 1967).

65 See, e.g., Haynes v. United States Pipe \& Foundry Co., 362 F.2d 414, 418 (5th Cir. 1966).

66 Simmons v. Union News Co., 341 F.2d 531 (6th Cir.), cert. denied, 382 U.S. 884 (1965) (Warren, C.J. \& Black, J., dissenting); Hildreth v. Union News Co., 315 F.2d 548 (6th Cir.), cert. denied, 375 U.S. 826 (1963); Union News Co. v. Hildreth, 295 F.2d 658 (6th Cir. 1961).

67382 U.S. 884 (1965). 
The Union Neres cases appear to bar individual employee suits subsequent to a union-employer settlement. ${ }^{68}$ But the recently expanded duty of fair representation may diminish their force, because no attempt was made in those cases to invalidate the union-employer settlement by showing a violation of that duty.

\section{Development of the Duty of Fair Representation as a Standard for Determining When an Employee May Process His Own Grievance Against the Emiployer}

To understand how the duty of fair representation acquired the function of deciding in most situations when an employee can process his grievance on his own, despite a provision in the collective bargaining contract granting the union absolute control over the processing of grievances, requires an examination of a series of judicial and administrative developments, culminating in the Supreme Court's decision in Vaca $v$. Sipes. ${ }^{69}$

The duty of fair representation originated as a substantive check ${ }^{70}$ upon the union's negotiating power. Its first call to battle came in Steele v. Louisville \& Nashville Railroad Co., ${ }^{71}$ a particularly compelling case because the unfairness was alleged to be based on racial discrimination. A Negro employee brought suit against his employer and the union to enjoin the enforcement of a contract, negotiated by the employer and union, which allegedly discriminated against him because of his race. Reversing the denial of an injunction, Chief Justice Stone held that because the recipient of the Railway Labor Act's ${ }^{72}$ designation as bargaining representative has the responsibility "to exercise fairly the power conferred upon it in behalf of all those

6s In Haynes v. United States Pipe \& Foundry Co., 362 F.2d 414 (5th Cir. 1966), the court observed that Smith opened the door to employee claims under the contract, but the Union News cases barred them. Almost every collective bargaining agreement provides for binding final determination, whether by arbitration, by unionemployer agreement, or implicitly by union acquiescence in employer action. See Comment, Section 301(a) and the Employee: An Illusory Remedy, 35 FORDHAM I. REv. 517, 518-19 n.16 (1967) [hereinafter cited as Comment, Section 301(a) and the Employee].

69386 U.S. 171 (1967).

70 The word "substantive" means that a violation of the duty is deemed to be grounds for a suit against the union for relief, whether the relief sought be damages, a negative injunction, or a mandatory injunction. Subsequent discussion referring to the other role of the duty of fair representation, in which proof of its violation provides the means of overcoming an employer defense based on the exclusive grievance provisions of the contract, refers to the duty in its "exhaustion" role.

71323 U.S. 192 (1944).

7245 U.S.C. $\$ \$ 151-88$ (1964), as anended, (Supp. IV, 1969). For other cases interpreting the duty under this Act, see Glover v. St. Louis-S.F. Ry., 393 U.S. 324 (1969) ; Conley v. Gibson, 355 U.S. 41 (1957) ; Brotherhood of R.R. Trainmen v. Howard, 343 U.S. 768 (1952) ; Tunstall v. Brotherhood of Locomotive Firemen, 323 U.S. 210 (1944). 
for whom it acts, without hostile discrimination against them," ${ }^{73}$ an employer could not rely on or benefit from an agreement with the union in which the union had violated this duty. In the courts, this duty of fair representation as a substantive limitation on union conduct grew to encompass other situations. The NLRA ${ }^{74}$ was read to impose the same duty on its bargaining representatives; ${ }^{75}$ unfairness other than racial discrimination was viewed as violating the duty; ${ }^{76}$ and the duty was applied to the union's processing of grievances as well. ${ }^{77}$

While the courts examined possible applications of the duty of fair representation, the National Labor Relations Board finally sought to assert its jurisdiction over conduct violating the duty. In Miranda Fuel Co., ${ }^{78}$ the Board held, inter alia, that the protection afforded to employees by section 9 (a)'s ${ }^{79}$ imposition on the union of a duty of fair representation was subsumed in the rights granted in section 7 of the NLRA ${ }^{50}$ to employees. Consequently, a violation of the duty constituted an unfair labor practice under section $8(\mathrm{~b})(1)(\mathrm{A})$ of the NLRA $^{s 1}$ in that it restrained and coerced employees in the exercise of rights guaranteed by section 7 "to bargain collectively through representatives of their own choosing." In finding a section 7 right to fair representation, the Board concluded that unfair, irrelevant, or invidious treatment by the exclusive bargaining agent in matters affecting employment was an unfair labor practice. Although the Board's order was denied enforcement by the Second Circuit, ${ }^{82}$ a majority of the court

73323 U.S. at 203.

7429 U.S.C. \$§151-68 (1964).

75 Syres v. Oil Workers Local 23, 350 U.S. 892 (1955); Wallace Corp. v. NLRB, 323 U.S. 248 (1944). Although the Court's per curiam opinion in Syres only cited Steele and several other Railway Labor Act cases, without reference to any particular provision of the NLRA, the duty is derived from $\$$ 9's conferral on the union of the status of exclusive representative of the bargaining unit. See 29 U.S.C. \$159(a) (1964).

76 See Ford Motor Co. v. Huffman, 345 U.S. 330, 337 (1953).

77 See Hughes Tool Co. v. NLRB, 147 F.2d 69, 74 (5th Cir. 1945).

78140 N.L.R.B. 181 (1962), enforcement denied, 326 F.2d 172 (2d Cir. 1963). A contractual provision allowed an employee to take a leave of absence during the slack season from April 15 to October 15 without losing seniority. When an employee took such a leave on April 12 with the employer's permission, but did not return until October 30 due to illness, the union initially claimed he had lost his seniority. When the company insisted upon excusing the employee for his late return, the union countered by claiming he had lost his seniority by leaving early. The union's second claim was made only after a vote by the employee's fellow union members that he should lose his seniority, and notwithstanding a prior judicial interpretation of the contract holding that only a late return was sufficient grounds for loss of seniority. This action by the union was the basis for the Board's holding that the union had acted hostilely and in violation of its duty to act fairly and impartially in its representative capacity.

7929 U.S.C. $\$ 159$ (a) (1964).

80 Id. § 157 .

81 Id. $\$ 158$ (b) (1) (A).

82326 F.2d 172 (2d Cir. 1963). 
was unable to agree whether a breach of the duty of fair representation is an unfair labor practice.

Notwithstanding the doubts raised by the Second Circuit's disposition, the Board continued to apply its doctrine. In Independent Metal Workers Union [Hughes Tool Co.], ${ }^{83}$ the Board held that racial discrimination in processing of grievances did violate section 8(b) (1)(A). In asserting jurisdiction on the basis of a breach of the duty of fair representation, the Board acknowledged that it was enforcing a duty originally created judicially under the Railway Labor Act in Steele, but justified its action by pointing to the Court's language in Steele and subsequent cases emphasizing the lack of administrative remedies under the Railway Labor Act as a reason for judicial creativity. Once the Taft-Hartley Act created unfair labor practices against unions, however, an administrative remedy became available. ${ }^{84}$

By the time Vaca reached the Court, two other cases ${ }^{85}$ in which the Board had found breaches of the duty of fair representation to be unfair labor practices were before the Fifth Circuit. Both cases involved racial discrimination as the basis for finding a violation of the duty of fair representation and an unfair labor practice. Despite the strength of these two cases and the Fifth Circuit's enforcement of the orders in the context of racial discrimination, the breadth of the duty of fair representation as the basis for an unfair labor practice in other circumstances was uncertain. Although some of the language in the Fifth Circuit's opinion in Local 12, United Rubber Workers $v$. $N L R B^{86}$ suggested that the merits of the employees' substantive grievances might be relevant, the status and relevance of this factor as well as others in making determinations of such unfair labor practices was not explored.

Whatever the status of a breach of the duty of fair representation as an unfair labor practice, the possibility after Miranda Fuel that it might constitute activity subject to sections 7 or 8 of the NLRA suggested a new hurdle to overcome in a suit against the union when a breach of the duty had been alleged: ${ }^{87}$ preemption by the NLRB on the

83147 N.L.R.B. 1573 (1964).

84 Id. at 1575.

85 Local 12, United Rubber Workers, 150 N.L.R.B. 312 (1964), enforced, 368 F.2d 12 (5th Cir. 1966), cert. denied, 389 U.S. 837 (1967); Local 1367, International Longshoremen's Ass'n, 148 N.L.R.B. 897 (1964), enforced, 368 F.2d 1010 (5th Cir. 1966), cert. denied, 389 U.S. 837 (1967).

86368 F.2d 12, 17-18 (5th Cir. 1966), cert. denied, 389 U.S. 837 (1967).

87 Prior to Miranda Fuel, many actions involving breaches of the duty of fair representation had been decided without even raising the possibility of preemption by the NLRB. See, e.g., Trotter v. Amalgamated Ass'n of Street Ry. Employees, 309 F.2d 584 (6th Cir. 1962), cert. denied, 372 U.S. 943 (1963); Hardcastle v. Western Greyhound Lines, 303 F.2d 182 (9th Cir.), cert. denied, 371 U.S. 920 (1962). Even when the issue was raised, courts seemed to think that the Board's 
basis of its exclusive jurisdiction. ${ }^{88}$ At least when the substantive allegation against the union is combined with a section 301 breach-ofcontract action against the employer, Justice White laid to rest any doubts about this issue with a mere two sentences and a footnote in Humphrey v. Moore. ${ }^{89}$ Once a complaint against the employer alleges a violation of the contract, the case will be fully adjudicated under federal labor contract law, ${ }^{90}$ regardless of whether a violation of the substantive duty of fair representation is an unfair labor practice, ${ }^{91}$ because the contract action will be properly within the cognizance of the federal or state court. ${ }^{92}$ This result was facilitated by the Court's previous decision ${ }^{93}$ that under section 301 -at least in the absence of a contractual provision granting the union absolute control over the grievance procedures - an individual employee could sue the employer for breach of the collective bargaining agreement even though the alleged action by the employer constituted an unfair labor practice.

The preemption question posed in $V a c a$ was the next step: would preemption preclude judicial cognizance of the substantive duty of fair representation when the action did not involve a section 301 contract action against the employer as in Humphrey? The Court's negative response to the question refused to deal with it directly. Instead it concentrated on an analysis of the duty's role in a third situation ${ }^{94}$

inaction precluded preemption. See, e.g., Berman v. National Maritime Union, 166 F. Supp. 327 (S.D.N.Y. 1958).

88 See Building Trades Council v. Garmon, 359 U.S. 236 (1959).

89375 U.S. $335,344-45$ n.6 (1964).

90 Id. at $343-44$ (citing Teamsters Local 174 v. Lucas Flour Co. 369 U.S. 95 , 102-04 (1962); Textile Workers Union v. Lincoln Mills, 353 U.S. 448, 456-67 (1957)).

91 For a discussion of the undesirability of preemption when an unfair labor practice is part of a $\$ 301$ action, see Sovern, Section 301 and the Primary Jurisdiction of the NLRB, 76 HARV. L. REv. 529 (1963).

92375 U.S. at $344-45$ n.6 (citing Charles Dowd Box Co. v. Courtney, 368 U.S. $502(1962))$.

93 Smith v. Evening News Ass'n, 371 U.S. 195 (1962).

94 Justice White also discussed several other general points supporting flexibility in avoiding the preemption doctrine. First, Congress itself created several exceptions to the doctrine's application: the LMRA \& 303,29 U.S.C. $\$ 187$ (1964), expressly allows anyone damaged by action in violation of the NLRA $\$ 8(b)$ (4), 29 U.S.C. $\S 158(\mathrm{~b})(4)$ (1964), to collect damages in a federal court; the LMRA $\$ 301,29$ U.S.C. § 185 (1964), permits suits for violations of collective bargaining agreements even though the suit is based on action arguably an unfair labor practice; and the NLRA § 14, 29 U.S.C. \$164(c) (1964), permits state agencies and courts to assert jurisdiction over certain labor disputes where the NLRB refuses to exercise its jurisdiction to the fullest extent. Vaca v. Sipes, 386 U.S. 171, 179-80 (1967). Second, control of activity of peripheral concern to the NLRA or of compelling concern to local interests (libel, violence, wrongful expulsion from union membership, mass picketing) had not been preempted. Id. at 180. Third, the NLRB's inability to give complete relief by itself under certain circumstances, and the possible lack of any remedy in cases in which the NLRB's general counsel, in his unreviewable discretion, fails to issue a complaint, both militate against the NLRB's exclusive jurisdiction. Id. at 182-83. Fourth, the duty of fair representation was developed judicially in Steele v. Louisville \& N.R.R., 323 U.S. 192 (1944), and the Board 
its exhaustion role in employee suits against the employer under a collective bargaining agreement-a role not specifically raised or argued, but created by the Court. ${ }^{95}$

$[T]$ he wrongfully discharged employee may bring an action against his employer in the face of a defense based upon the failure to exhaust contractual remedies, provided the employee can prove that the union as bargaining agent breached its duty of fair representation in its handling of the employee's grievance. ${ }^{96}$

Given the holding in Humphrey of nonpreemption in combination section 301-duty of fair representation actions already mentioned, and given its decision to resist preemption in garden variety section 301 employee suits against employers by placing the duty of fair representation in an exhaustion role, the Court was unlikely, whether or not violation of the duty is an unfair labor practice, to remit to the exclusive jurisdiction of the NLRB the question whether employee suits against unions alone for breach of the duty were preempted. Although in Vaca the Court faced an action against the union alone, unattached to a section 301 claim against the employer, it disposed of the distinction with little discussion, suggesting that reliance on preemption was unnecessary to secure consistency in the development of the duty because courts would be dealing with the duty of fair representation in section 301 cases anyway. ${ }^{27}$

In Vaca, the Court resolved a previously undecided issue in an effort to bolster its nonpreemption argument in a questionable case. ${ }^{98}$ Despite Justice Black's fears that the Court failed to advance employee protection sufficiently, ${ }^{99}$ the Court did little more than supply the label-

is unlikely to have greater expertise in the cases just described, especially in light of the duty's recent development and the frequent presence of grievance issues. 386 U.S. at $181-82$.

Justice Fortas' concurring opinion viewed the preemption question differently. Arguing for preemption, he viewed the NLRB as the body to strike the balance between the employee and his union. Id. at 198-203 (Fortas, J., concurring).

95 Lewis, Fair Representation in Grievance Adninistration: Vaca v. Sipes, 1967 Suprese Court Review 81, 85-88 [hereinafter cited as Lewis].

96386 U.S. at 186 (footnote omitted).

97 Recognizing that $\$ 301$ claims are always a threat to uniformity in the application of $\$ \$ 7$ and 8 , the Court might have held that substantive claims based on the latter sections are preempted unless joined with a $\$ 301$ claim as in Humphrey. Such a holding would have at least confined some development of unfair labor practices law to the NLRB. By eliminating all possibilities of preemption, the Court created a situation in which the duty of fair representation as the exhaustion standard in the run-of-the-mill $\$ 301$ contract suit by the employee will be substantially litigated in the courts. Thus, any vestiges of NLRB control of the development of that law vanished.

98 For criticism of the Vaca decision, see Lewis; Note, Individual Control Over Personal Grievances Under Vaca v. Sipes, 77 YALE L.J. 559 (1968).

99 [T] Joday's decision, requiring the individual employee to take on both the employer and the union in every suit against the employer and to prove not only that the employer breached its contract, but that the union acted arbi- 
exhaustion-to be used in section 301 suits against the employer when the employee alleges failure to comply with the grievance procedures because of the union's breach of the duty of fair representation. The dearth of fair representation litigation both in the courts and before the Board prior to $V$ aca suggests that its application, especially in its new exhaustion role, is yet to be fully explored. Whether the VacaHumphrey line of cases can be read to suggest a more liberal attitude toward employee protection under the contract than might be initially expected from their language or from the views of some pessimistic commentators ${ }^{100}$ now depends upon the flexibility of the doctrine of the duty of fair representation.

\section{The Role of Contractual Provisions in Determining Violations of The Duty of FaIR Representation}

\section{A. Giving Content to the Duty of Fair Representation}

The statutory duty of fair representation is only violated "when a union's conduct toward a member of the collective bargaining unit is arbitrary, discriminatory, or in bad faith." 101 In making this determination, "[a] wide range of reasonableness must be allowed a statutory bargaining representative in serving the unit it represents, subject always to complete good faith and honesty of purpose in the exercise of its discretion." 102

A union decision favoring one group of employees is not necessarily arbitrary. A union must constantly balance the interests of various groups of employees, and some choices inevitably benefit one group and harm another. ${ }^{103}$ A court will invoke the duty of fair representation only when the facts are compelling. In Chasis $v$. Progress Manufacturing Co., ${ }^{104}$ the employer discharged the plaintiffs-employees for lacking the qualifications to work in an electrical fixtures plant. The court found sufficient to invoke the duty an allegation that the union maliciously conspired with the employer to cause the employees to lose their jobs and, while discouraging the employees from filing

trarily, converts what would otherwise be a simple breach-of-contract action into a three-ring donnybrook. . . Today's decision, while giving the worker an ephemeral right to sue his union for breach of its duty of fair representation, creates insurmountable obstacles to block his far more valuable right to sue his employer for breach of the collective bargaining agreement.

386 U.S. at 210 (Black, J., dissenting).

100 See Comment, Section 301(a) and the Employee; Note, The Duty of Fair Representation and Its Applicability When a Union Refuses to Process an Individual's Grievance, 20 S.C.L. REv. 253 (1968); Note, supra note 98.

101386 U.S. at 190.

102 Ford Motor Co. v. Huffman, 345 U.S. 330, 338 (1953).

103 Conflict between employees represented by the same union is a recurring fact.

Humphrey v. Moore, 375 U.S. 335, 349-50 (1964).

104382 F.2d 773 (3d Cir. 1967). 
unfair labor practice charges within the NLRA's six-month statute of limitations, refused to process the grievance or file the charge with the NLRB. ${ }^{105}$ Allegations of racial discrimination are also sufficient. ${ }^{106}$

But limiting the violations of the duty of fair representation to union conduct evidencing a motivation such as maliciousness or racial discrimination vests too much discretion in the union to disregard the contractual provisions authorizing it to act. Subtle discriminations or simple unfairness will be almost impossible to prove. ${ }^{107}$ To broaden employee protection under the duty of fair representation, the substantive provisions of the collective bargaining agreement should be used to limit the union's discretion in settling grievances ${ }^{108}$ and the employer's ability to rely on wrongful union conduct as a defense.

Humphrey is authority for the proposition that the substantive provisions ${ }^{109}$ are relevant in determining the fairness of the union's 1967).

105 See also Richardson v. Communication Workers, 267 F. Supp. 403 (D. Neb.

100 See Syres v. Oil Workers Local 23, 350 U.S. 892 (1955) ; Steele v. Louisville \& N.R.R., 323 U.S. 192 (1944). The union may also violate the duty of fair representation by utilizing its control over the grievance machinery to enforce union discipline. Such activity, and certain union complicity in employer-designed discipline procedures, may even subject the action to the procedural requirement of the Labor-Management Reporting and Disclosure Act, $\$ 101$ (a) (5), 29 U.S.C. $\$ 411$ (a) (5) (Supp. IV, 1969). See also Blumrosen, Three Phases of Unionism, supra note 23, at 1501-03; Rosenberg, Interpretive Problems of Title I of the LaborManagement Reporting and Disclosire Act, 16 IND. \& LAB. REL. REV. 405, 424-27 (1963).

107 Furthermore, there are a number of reasons why a worker might believe that his interest is not properly served by the union's handling of a grievance. First, the worker and the union might merely have a bona fide disagreement as to the interpretation of a provision of the collective agreement, or they might otherwise disagree as to the merits of his grievance or claim. Second, the worker might think he has reason to fear union favoritism. A worker might believe that his interests are either being opposed or inadequately represented because he belongs to a disfavored racial, ethnic, sex or age class or that he is personally obnoxious to the union leaders or membership. On the level of internal union politics, an individual may fear that union power will be abused because he is not a member or because he belongs to the political opposition or a different union. An individual might also fear that, to his detriment, he simply does not have as much political influence within the union as other individuals who are backing interests in opposition to his. Third, workers might have reason to fear that bureaucratic inefficiency or prejudice will result in "incomplete investigation of the facts, reliance on untested evidence, or colored evaluation of witnesses [that] may lead the union to reject grievances which more objective inquiry would prove meritorious." Finally, there might be reason to believe that over-zealous concern for institutional interests of the union and the collective enterprise will induce union officials to trade off unrelated grievances or make wholesale settlements that relinquish some meritorious claim or even to accept resolutions, that very much lack in personal justice, of some grievances.

Rosen, The Individual Worker in Grievance Arbitration: Still Another Look at the Problem, 24 Mn. L. Rev. 223, 245-46 (1964) (footnotes omitted) [hereinafter cited as Rosen]. For an illustration of manipulation of grievances, see R. JAMES \& E. J J AMES, Hoffa AND THE TEaMsTERS 167-85 (1965).

108 See Lewis 112-13.

100 The Steelworkers Trilogy indicates how expansively the "substantive provisions" of the collective bargaining agreement can be construed. Neither the contractual language nor ordinary contract law is the only source of interpretation. Though necessarily based on the "essence" of the contract, a sound interpretation 
representation. In that case, the Court examined the collective bargaining agreement to determine whether a joint committee composed of union and employer representatives exceeded its authority under the agreement. The Court did not regard the issue as one of fair representation, but its examination of the employer-union resolution rested on the assumption that the relevant substantive provisions of the collective bargaining agreement circumscribed the joint committee's power to integrate two seniority lists and subjected its interpretation to court review. ${ }^{110}$ In short, union agreement to a resolution beyond the limits of the bargaining agreement does not bind the employees. Although the Court found that the union and employer reasonably interpreted the contractual provision, its decision does not diminish the significance of its efforts to determine whether the resolution rested upon some "rational basis" consistent with an equitable resolution of inevitably conflicting interests. ${ }^{111}$ Moreover, the Court elsewhere affirmed its power to define the scope of the power granted the union. ${ }^{112}$

\section{B. Standards for Judicial Review of a Union's Disposition of an Employee Grievance}

A finding that an employee's grievance is meritorious satisfies only the first of $V$ aca's two requirements. To support its intervention in the grievance-arbitration procedures, a court must also find that the union's disposition of the employee's grievance breached its duty of fair representation. ${ }^{113}$

also includes the "common law of the shop." See United Steelworkers v. Warrior \& Gulf Navigation Co., 363 U.S. 574, 578-82 (1960). Although this practice of construing the substantive provisions broadly arose in the context of granting flexibility to a mutually agreed-upon third party expert, interpreting the parties' own decisions with less flexibility would produce the anomaly of imposing different standards of contractual interpretation for different stages of the grievance-arbitration process. But see 375 U.S. at 352-55 (Justice Goldberg, concurring in Humphrey, rejected the analogy to the arbitration decisions on the ground that the employer and union are always free to alter their agreement, whereas the arbitrator is limited to its terms).

110375 U.S. at 345.

111 See id. at 347 .

112 Id. at $345-46 \mathrm{n} .8$.

113 Situations may arise in which the first requirement of Vaca-that the employee prove a breach of contract-should not be rigorously enforced if the courts wish to maintain the remedial flexibility to send the case to arbitration on the merits. If the court orders the case to arbitration only to secure the "best interpretation of the contract" (Has the contract been breached?), it need not first find a breach of contract. If a breach of the duty of fair representation is found because, for example, the union's interpretation completely disregarded the contract, the court might prefer an arbitrator to select among alternative contract interpretations. Since the results of the resort to arbitration would probably be predictable once the court itself selected its own interpretation of the contract, the court would undermine the arbitrator's freedom by interpreting the contract itself. Although authorized under the Steelworkers Trilogy to formulate an independent interpretation, the arbitrator would be unlikely to deviate from the court's position. Consequently, the first requirement should be modified in at least some cases so that the employee must 
The contrast between the majority and the dissent in Vaca highlights the conflicting considerations in fair representation questions. The majority sought to preserve the integrity of the arbitral process by restricting an employee's ability to compel arbitration of contractual claims already settled by the union and employer, ${ }^{114}$ although it probably did not intend to preclude all third party review of employee claims. ${ }^{113}$ Fearing that the Court's decision encouraged the union and the employer to override an individual employee's expectations, however, Justice Black argued that the majority sacrificed employee rights to institutional power. By denying the employee the absolute right to invoke the check upon union abuse provided by arbitration, the Court, he noted, also acted inconsistently with its recent preference for arbitration. ${ }^{116}$

Whether the union has breached its duty of fair representation in situations like Vaca depends on whether the union was correct in settling the grievance before arbitration. To enable courts to resolve this question adequately, two alternative standards are herein proposed to provide the employee with third party review of the union's decision that arbitration would be fruitless, yet insulate the arbitral process from frivolous claims.

At a minimum, a court should look to the contract itself and evaluate the union's disposition of an employee's grievance by a standard at least as strict as that for reviewing the acceptability of an arbitrator's award. An arbitrator's disposition of a question arising under the contract is unacceptable when he exceeds his authority by failing to draw upon the "essence" of the contract in making his de-

show only that the interpretation he advocates is acceptable and that the union violated its duty of fair representation. When the employee wants the court, not the arbitrator, to grant full relief and decide the issue of the interpretation of the contract, he must, of course, prove a breach before the court. This modified rule would also be appropriate when the employee approaches the union with a grievance based on a meritorious interpretation of the contract, after satisfying the requirements of Maddox by initially resorting to the grievance procedures, and the union fails to respond in any way, see Desrosiers v. American Cyanamid Co., 377 F.2d 864, 867 (2d Cir. 1967), or fails to investigate the situation and take action until coerced by a pending suit, see Williams v. Wheeling Steel Corp., 266 F. Supp. 651, 654 (N.D.W. Va. 1967). Again, if the court prefers to have the arbitrator actually interpret the contract, the union's subsequent adoption of the employer's justification of his action should not insulate the union or employee from an arbitrator's decision, as a violation of the duty of fair representation has already been found (by the court) to have occurred. The duty of fair representation seeks to further union representation of employee interests, not their disregard. Of course, the union might long ago have adopted the employer's position as its own; but the union should be careful to communicate this to the grieving employee.

114386 U.S. at 190-92 (citing NLRB v. Acme Indus. Co., 385 U.S. 432, 438 (1967); Ross, Distressed Grievance Procedures and Their Rehabilitation, LABOR Arbitration and Industrial Change, Proceedings of the 16th Annual Meeting, National Acadeary of Arbitrators 104 (1963)).

115 Contra, Humphrey v. Moore, 375 U.S. 335, 357 (1964) (Goldberg, J, concurring).

110386 U.S. at 207 (Black, J., dissenting). 
cision. ${ }^{117}$ In disposing of an employee's grievance under the contract, the union and employer should not be able to exceed this limit imposed upon a neutral third party's discretion. The court would thus initially decide if an arbitrator would be permitted under the contract to accept the union's disposition of the employee's grievance. If he would not, the union has violated its duty of fair representation.

Yet the narrow scope of the arbitration review standard proposed above and its explicit rejection of any judicial review of the merits of an arbitration ${ }^{118}$ point to the need for a standard affording employees even greater protection under the duty of fair representation. Neither cost, inconsistency, nor protection of the arbitral process justifies judicial deference, merely because preferred by the union, to a settlement likely to be found unacceptable on its merits by an arbitrator, even if he would be permitted to accept it without overreaching the bounds of his authority. Justice Black's possible overstatement in Vaca of the need for resort to arbitration does not vitiate the implication of his argument: standards similar to those used in arbitration itself should govern judicial intervention in the arbitral process. A standard permitting a court to predict an arbitrator's probable evaluation of the merits of competing contractual interpretations of the grievance's validity would more effectively curb union abuse than the arbitration review standard. This broader standard would not require a court to make a de novo contractual interpretation, but would enable it to reject not only interpretations judicially unenforceable as arbitration awards but also union positions it believes an arbitrator would not accept. If the court determines that an arbitrator would favor the union's interpretation, the arbitral process is spared the cost of the grievance. But arbitration would be ordered if the employee's claim appears not only meritorious but also able to win the arbitrator's favor. Even if a court orders arbitration, however, its rejection of the union's position would not bind the arbitrator. Because its preliminary examination is conducted under a broader standard than its review, a court might uphold an arbitrator's acceptance of a union interpretation it previously rejected.

In light of the Court's explicit refusal to review an arbitration award's merits, this broader standard of review does not fit neatly within the arbitration analogy. Courts have never employed such a standard in arbitration cases, and they would also face the task of prearbitration prediction without the expertise of arbitrators. But the standard would afford an employee neutral third party review of his claim.

117 See United Steelworkers v. Enterprise Wheel \& Car Corp., 363 U.S. 593, 597 (1960).

118 Id. at 596. 
The special expertise of arbitrators in the area of collective bargaining does not preclude courts from preliminarily interpreting the contract in this special instance. Judges frequently interpret contracts without arbitration clauses. The Supreme Court's decision to submit most of the jurisdictional and substantive questions first to the arbitrator and to enforce his awards with minimal review should not bar the application of arbitral standards in other circumstances. The suggested standard is particularly appropriate in duty of fair representation cases. First, courts will probably find few union violations of the duty of fair representation; thus, few cases will go to an arbitrator. Second, an argument based on the fear that the employer-union grievance-arbitration process may be undermined is not compelling when the process itself is challenged as unfair.

\section{Implications of an Expanded Duty of FAIR REPRESENTATION}

Expansion of the duty of fair representation in section $301 \mathrm{em}-$ ployee suits against employers through reliance upon the contractual provisions should encourage aggrieved employees and stimulate union responsiveness. But use of an expanded duty is questionable when the substantive liability of the union or a violation of the duty as an unfair labor practice is at issue.

In $V a c a$, the Court apparently used the duty of fair representation as a single standard for defining both the union's substantive duty and the limits of an employee's ability to overcome an employer's exhaustion defense. ${ }^{119}$ In his dissent in Vaca, however, Justice Black recognized that the duty might define two different standards:

If the Court here were satisfied with merely holding that in this situation the employee could not recover damages from the union unless the union breached its duty of fair representation, then it would be one thing to say that the union did not do so in making a good-faith decision not to take the employee's grievance to arbitration. But if, as the Court goes on to hold, the employee cannot sue his employer for breach of contract unless his failure to exhaust contractual remedies is due to the union's breach of its duty of fair representation, then I am quite unwilling to say that the union's refusal to exhaust such remedies-however nonarbitrary-does not amount to a breach of its duty. ${ }^{120}$

Because he viewed the section 301 action as more important, he was willing to apply a narrower substantive standard to define a breach 
of the duty of fair representation in suits against unions so long as the standard is relaxed when the duty plays an exhaustion role in suits against employers. Yet if, as is recommended here, the duty as it is used in section 301 suits is expanded by reference to provisions in the collective bargaining agreement, the question arises whether expansion is necessary or desirable in suits against the union for breach of its substantive duty.

The need for remedial flexibility calls for application of the same standard-the broadened one recommended herein-in suits against the union as well as in section 301 suits against the employer. To apply a more lenient standard in a section 301 suit against the employer than in a suit against the union alone would mean that the same circumstances justifying an action directly against the employer under section 301 might not justify an action against the union to compel it to arbitrate a grievance. The entire grievance procedure, upon which the court has been relying, would be undermined, because the employee could sue the employer directly more easily than he could sue the union to compel its proper functioning under the grievance procedures. Assuming that it is desirable to allow courts to fashion relief within the framework of the grievance-arbitration procedures provided in the contract, then the standards must be the same.

Arguments supporting a narrow substantive standard are grounded on fears that such suits will be a source of exacerbation of political and personal disputes within the union, cause unnecessary expense to the union, and fail to speak to the major concern: enforcement of the employer's contractual obligations. But these arguments fade if the remedy is confined either to compelling the union to operate within the contractual procedures to pursue employee rights, allowing employees themselves to operate within the contractual grievance-arbitration procedures, or allowing the employees to bypass completely such procedures as they seek remedies in court. All of these remedies are directed to and result in enforcement of the substantive provisions of the contract against the employer, and not in relief against the union.

But when the employee seeks damages against the union, as he did in Vaca, either in a suit against the union alone or against both employer and union, the threat to the union is more substantial and direct. To award damages in this case to compensate the injured employee for a past event can foster proper union conduct only insofar as the threat of such an award recalls the union to its vulnerability. The award in any individual case does not help resolve the underlying breach of contract claim precipitating the entire action. Indirect pressure as a means of promoting enforcement of contract rights may be misdirected. To threaten the union with damage actions when other 
remedies would be appropriate invites the use of such suits as a means of engaging in union political struggles.

Perhaps in recognition of this problem, the Vaca Court did manage to provide unions some protection. It limited the prospects of recovery against them by denying recovery for damages attributable solely to the employer's breach of contract, and although it pointed out that damages should be apportioned between the employer and union according to the damages caused by the fault of each, it noted that in most cases the employer's breach will be the only wrong for which damages are appropriate. ${ }^{121}$ Thus, although it appears that the duty of fair representation will be defined according to one standard in suits against unions and against employers and unions, actions for damages against unions will be severely limited.

The implications of an expanded duty of fair representation must also be examined when considering a violation of the duty as an unfair labor practice. That the Court has avoided two opportunities ${ }^{122}$ to deny that a violation of the duty of fair representation constitutes an unfair labor practice cannot help but give impetus to those advocating that the NLRB's position is correct. Assuming that violation of the duty constitutes an unfair labor practice, vesting jurisdiction in the Board, the question arises whether the scope of the duty as applied by the Board need be expanded as recommended herein. If in fact it chooses to expand the duty, it may well draw much business from the courts (assuming that the courts refuse expansion), at least in actions seeking relief against the union. And because the General Counsel bears the expense of processing the action, aggrieved employees have an added incentive to turn to the Board.

Yet the relief sought in most actions under collective bargaining agreements will be against the employer and will entail interpretation of contractual provisions. But the Board is unable to provide ap-

121 The Court noted that it was not dealing with a situation in which a union affirmatively caused the employer to breach the contract. Alluding to the NLRB's imposition of joint and several liability for back pay when combined union and employer discrimination has injured an employee, the Court distinguished $V a c a$ as a case of a breach of contract with no union participation. Id. at $197 \mathrm{n} .18$. The Court did not deal with the more difficult question posed by Humphrey: namely, whether a union participates in a breach of contract when the breach of contract and violation of the duty of fair representation arise from joint employer-union efforts to "apply" the terms of the contract. If a violation of the duty of fair representation had been found in Humphrey and if the employees had sought damages, this issue would have been posed. In light of the language employed by the Court, it seems that mere cooperation by the union in the employer's breach of contract would not justify joint and several liability; the Court suggests that to be liable in damages, the union must have "affirmatively cansed the employer to commit the alleged breach of contract." Id. (emphasis added). (1964).

122 Vaca v. Sipes, 386 U.S. 171 (1967); Humphrey v. Moore, 375 U.S. 335 
propriate and complete relief in many such cases, ${ }^{123}$ and is generally reluctant to immerse itself in the administration of collective bargaining agreements or interfere with grievance-arbitration procedures. ${ }^{124}$ Thus its activity may be restricted to finding a violation of the duty of fair representation only in those cases where union discrimination, hostility, or arbitrariness can be proven without resort to the contractual provisions, ${ }^{125}$ or where the violation occurs during the negotiation of the agreement. Furthermore, an aggrieved employee may turn to the courts in hopes of securing a more sympathetic hearing from a jury than he might otherwise from the Board.

Although the Board has indicated a willingness to more actively enforce the duty of fair representation, ${ }^{126}$ the relationship between its role and that of the courts remains unclear. If the judicially developed duty of fair representation refuses the expanded definition recommended here, pressure may be brought upon the Board to expand its reading of the duty. If the Board responds favorably, the irony of Vaca will be that the very case denying preemption by the Board of duty of fair representation cases will have caused many grieving employees to resort to the Board as the only viable source of protection.

\section{CONCLUSION}

This analysis has sought to develop a conceptual framework within the current system of standards to strike a new balance among union, employer, and employee without disturbing the legitimate values protected by the old. The Supreme Court encouraged, if not required, those living in the world of industrial relations to focus on the collective bargaining agreement to define their relationships therein. To preserve the expectations generated thereby, the collective bargaining agreement should not be abused with impunity.

123 See 386 U.S. at 187-88.

124 See International Harvester Co., 138 N.L.R.B. 923 (1962).

125 See Truck Drivers Local 568 v. NLRB, 379 F.2d 137 (D.C. Cir. 1967).

126 Id.; Houston Maritime Ass'n, 168 N.L.R.B. 83 (1967); Cargo Handlers, Inc., 159 N..L.R.B. 321 (1966). But see Port Drum Co., 170 N.L.R.B. 51 (1968). 